\title{
STATUS KONFLIK BERSENJATA DI WILAYAH SABAH ANTARA KESULTANAN SULU DAN MALAYSIA DALAM PERSPEKTIF HUKUM HUMANITER INTERNASIONAL
}

Oleh :

\author{
Ikaningtyas ${ }^{1}$ \\ Fakultas Hukum Universitas Brawijaya
}

\begin{abstract}
Abstrak
Konflik bersenjata yang terjadi antara Pemerintah Malaysia dengan loyalis Sultan Sulu yang berkedudukan di Filipina sempat menjadi perhatian masyarakat internasional. Konflik bersenjata ini bermula pada awal Februari 2013, dimana sekitar 100-300 orang asal Filipina selatan mendarat di salah satu pantai di Negara Bagian Sabah, Malaysia dan menginisiasi konflik bersenjata. Tulisan ini bertujuan untuk menganalisis karakteristik sengketa bersenjata ini berdasarkan perspektif Hukum Humaniter Internasional. Telaah utamanya dilakukan terhadap kualifikasi konflik bersenjata berdasarkan Konvensi-Konvensi Jenewa 1949 dan Hague Regulations. Tulisan ini menyimpulkan bahwa status pasukan Kesultanan Sulu dalam sengketa ini dapat dikualifikasikan sebagai unlawful combatant. Sengketa bersenjata ini memiliki karakteristik pihak yang berbeda yaitu antara Pemerintahan suatu Negara yang sah dengan gerakan terorganisir yang berkedudukan di Negara lainnya. Dengan demikian, jenis konflik bersenjata antara loyalis Sultan Sulu-Filipina dan Pemerintah Malaysia ini termasuk ke dalam grey zone conflict.
\end{abstract}

Kata Kunci: Status, Konflik Bersenjata, Kesultanan Sulu, Filipina, Malaysia.

\section{Abstract}

The armed conflict between the Malaysian Government and the loyalist of Sultan Sulu, that residing in the Philippines was a concern of the international community. The armed conflict began in early February 2013, where about 100-300 people from the southern Philippines landed in a coastal area in Sabah State, Malaysia and then initiated an armed conflict. This article aims to analyze the characteristics of the armed conflict in concern based on the perspective of International Humanitarian Law. The main study was conducted on the qualification of armed conflict under the Geneva Conventions of 1949 and the Hague Regulations. This article concludes that the status of Sulu Sultanese troops in this armed conflict is an unlawful combatant. Such conflict has the characteristics of a different party between the Government of a legitimate State and an organized movement domiciled in the other State. Thus, the type of armed conflict between loyalists of Sulu Sultanese and Malaysian Government can be classified into a grey zone conflict.

Keywords: Status, Armed Conflict, Sulu Sultanese, the Philipines, Malaysia.

\section{Pendahuluan}

\subsection{Latar Belakang}

Salah satu konflik bersenjata yang sempat menjadi perhatian khusus masyarakat internasional adalah konflik bersenjata antara loyalis Sultan Sulu yang berkedudukan di Filipina dengan Pemerintah Malaysia. Konflik ini bermula pada awal Februari 2013 ketika Raja Muda Agbimuddin Kiram, adik Sultan Jamalul Kiram III dari Kesultanan Sulu di Filipina Selatan beserta sekitar 1.000 pengikutnya, termasuk pasukan bersenjata yang ia sebut Tentara Kerajaan Kesultanan Sulu dan Borneo Utara, meninggalkan Kepulauan Simunul di Tawi-tawi, Filipina

1 Ikaningtyas adalah Dosen Bagian Hukum Internasional Fakultas Hukum Universitas Brawijaya Malang. Korespondensi dengan penulis melalui email: ninktyas@ub.ac.id 
bagian Selatan. Mereka melaju ke Sabah dengan menggunakan kapal cepat. ${ }^{2}$ Fakta juga menyebutkan bahwa sekitar 100-300 orang asal Filipina selatan mendarat di salah satu pantai di Negara Bagian Sabah Malaysia dan kemudian membangun permukiman sementara di kota pantai Lahad Datu. ${ }^{3}$ Kehadiran warga yang mengaku keturunan dan utusan Kesultanan Sulu di Filipina itu mengaku membawa misi besar, yakni untuk mengklaim dan mengambil kembali tanah warisan leluhurnya di Sabah. ${ }^{4}$

Mengetahui teritorialnya dimasuki penyusup bersenjata, aparat keamanan Malaysia tidak tinggal diam. Kontak senjata terjadi pertama kalinya pada 1 Maret 2013, yang menewaskan 14 korban jiwa. ${ }^{5}$ Sehari setelahnya jumlah korban tewas dari kedua belah pihak mencapai 27 orang, pasca terjadinya baku tembak lagi di bagian lain Sabah. ${ }^{6}$

Setelah digempur habis-habisan oleh pesawat udara militer Malaysia, Kesultanan Sulu mengumumkan gencatan senjata sepihak yang ditandai oleh seruan Sultan Jamalul Kiram III kepada para pengikutnya yang masih bertahan di Sabah untuk tidak lagi menyerang pasukan Malaysia. ${ }^{7}$ Penyataan tersebut ternyata ditolak oleh Malaysia, yang melalui Menteri Pertahanannya Ahmad Zahid Hamidi, menegaskan bahwa Malaysia tidak akan melakukan gencatan senjata kecuali pihak pasukan Kesultanan Sulu menyerah tanpa syarat kepada Malaysia. ${ }^{8}$

Secara geografis, Kesultanan sulu terletak di antara Pulau Kalimantan dan kepulauan Filipina, tepatnya di antara Sabah dan pulau besar Mindanau yang berjejer ratusan kepulauan. Di kawasan tersebut terdapat tiga pulau utama: Pulau Basilian paling Utara, Jolo (sulu) di tengahtengah, dan Tawi-tawi paling Barat. Adapun pusat utama Kesultanan Sulu terletak di pulau Jolo (sulu). ${ }^{9}$ Tindakan kelompok bersenjata itu mengungkapkan kembali sejarah lama tentang Kesultanan Sulu. Wilayah Sabah masuk menjadi kekuasaan Kesultanan Sulu pada tahun 1658 atas pemberian Sultan Brunei sebagai tanda terima kasih atas bantuan para pejuang Tausug asal Sulu dalam menghapuskan pemberontakan pada 1660-1700-an di Brunei. ${ }^{10}$

Malaysia sebaliknya mengklaim kepemilikan Sabah berdasarkan Protokol Madrid 1885, ditandatangani Inggris, Jerman, dan Spanyol, yang menegaskan pengaruh Spanyol atas kepulauan Filipina. Dalam protokol itu, Spanyol melepas klaimnya atas wilayah Kalimantan Utara

2 Artikel, Perjalanan Pulang' Keluarga Sultan Sulu ke Sabah, Tempo.Co, 55 Maret 2013, Https://M.Tempo.Co/Read/ News/2013/03/05/115465135/Perjalanan-Pulang-Keluarga-Sultan-Sulu-Ke-Sabah

3 Artikel, Masa Lalu yang Belum Tuntas di Sabah, Kompas.com, 5 Maret 2013, http://bola.kompas.com/ $\mathrm{read} / 2013 / 03 / 05 / 08185514 /$ Masa.Lalu.yang.Belum.Tuntas.di.Sabah.

${ }^{4}$ Ibid.

${ }^{5}$ Ibid.

${ }^{6}$ Ibid.

7 Arfi Bambani Amri Akar Perang Sulu-Malaysia:Warisan konflik kolonial: Antara Bayar Sewa dan Penyerahan, Viva. co.id, 8 Maret 2013, http://sorot.news.viva.co.id/news/read/396304-akar-perang-sulu-malaysia

${ }^{8} \mathrm{Ibid}$.

${ }^{9}$ Alfigenk Ansyarullah, Sedikit Telaah Tentang Kesultanan Sulu dalam Konflik Sabah, Kompasiana, 8 Maret 2013, http:// www.kompasiana.com/alfigenk/sedikit-telaah-tentang-kesultanan-sulu-dalam-konflik-sabah_552085e4a33311ba4646cfde

${ }^{10}$ Rizki Roza, Konflik Sulu-Malaysia: Ancaman Terhadap Keamanan Kawasan?, Info Singkat, Hubungan Internasional, Pusat Pengkajian, Pengolahan Data dan Informasi (P3DI) Sekretariat Jenderal DPR RI, Vol. V, No. 05/I/P3DI/Maret/2013, http:// berkas.dpr.go.id/puslit/files/info_singkat/Info\%20Singkat-V-5-I-P3DI-Maret-2013-75.pdf 
atau Sabah. Berbeda halnya dengan Malaysia yang meyakini Filipina --sebagai penerus Kesultanan Sulu-- tidak memiliki kewenangan hukum atau kedaulatan atas Borneo Utara. ${ }^{11}$

Wilayah Sabah merupakan titik panas hubungan diplomatik di antara Malaysia dan Filipina, sejak penyerahan kedaulatan oleh Kesultanan Sulu. Upaya "mengambil alih" Sabah bahkan pernah diupayakan oleh Pemerintah Filipina pada masa kepemimpinan Presiden Ferdinand Marcos. ${ }^{12}$ Sengketa wilayah ini kemudian bertransformasi menjadi konflik: tidak ada yang mau mengalah, saling menyerang dengan senjata, tawaran perdamaian bahkan pun sudah tidak dihiraukan. ${ }^{13}$

Sejarah panjang sengketa antara kesultanan Sulu dan Malaysia ini pada akhirnya memicu terjadinya konflik bersenjata dengan karakter yang sangat berbeda terutama berkenaan dengan subyek hukum yang terlibat. Malaysia adalah sebuah Negara, namun loyalis Kesultanan Sulu sangat sulit dikategorikan sebagai representasi Negara Filipina, tetapi tidak bisa juga dikualifikasikan sebagai kekuatan pemberontak.

Ketidakjelasan subjek tentu berdampak pada kualifikasi sengketa bersenjata. Dalam $\mathrm{Hu}-$ kum Humaniter Internasional, sengketa bersenjata dibedakan antara sengketa bersenjata internasional dan sengketa bersenjata non-internasional. Sengketa bersenjata internasional adalah sengketa yang terjadi antara Negara (state actors) sedangkan sengketa bersenjata non -internasional adalah sengketa yang terjadi antara Negara dengan pihak pemberontak (belligerent-non State Actor).

\subsection{Tujuan, Pendekatan, dan Struktur Penulisan}

Berdasarkan fakta-fakta sebagaimana diuraikan pada bagian 1.1, terdapat dua isu hukum yang amat penting untuk dikaji, yakni berkaitan dengan status kombatan dan kualifikasi jenis sengketa bersenjata. Berangkat dari isu tersebut, tulisan ini bertujuan untuk menganalisis status pasukan Kesultanan Sulu dan untuk menganalisis klasifikasi sengketa bersenjata yang terjadi antara Kesultanan Sulu dan Malaysia dari perspektif Hukum Humaniter Internasional. Dalam rangka menganalisis kedua isu tersebut, digunakan metode yuridis normatif khususnya melalui pendekatan peraturan perundang-undangan, yaitu mengkaji instrumen-instrumen Hukum Humaniter Internasional terkait. Selain itu, digunakan pula pendekatan kasus dalam menganalisis kasus konflik bersenjata yang terjadi antara loyalis Kesultanan Sulu di SabahMalaysia pada tahun 2013.

\footnotetext{
${ }^{11}$ Reza Ilyasa, Herman Suryokumoro, Ikaningtyas, Serangan Bersenjata Kesultanan Sulu Terhadap Wilayah Sabah Malaysia Berdasarkan Perspektif Hukum Humaniter Internasional, h.10, https://media.neliti.com/media/publications/35369-ID-serangan-bersenjata-kesultanan-sulu-terhadap-wilayah-sabah-malaysia-berdasarkan.pdf

${ }^{12}$ Egidius Patnistik (ed), Liku-liku Sejarah Klaim Sabah, Kompas.com, 6 Maret 2013, https://app.kompas.com/amp/internasional/read/2013/03/06/08064895/Likuliku.Sejarah.Klaim.Sabah

${ }^{13}$ Adrianus Siburian dan Faisyal Rani, Diplomasi Malaysia Terhadap Kesultanan Sulu (Filipina) Dalam Perebutan Wilayah Sabah, 2013, http://repository.unri.ac.id/xmlui/bitstream/handle/123456789/6121/Jurnal\%20DIPLOMASI\%20MALAYSIA\%20 TERHADAP\%20KESULTANAN\%20SULU\%201.pdf?sequence=1
} 
Artikel ini akan disusun dengan struktur sebagai berikut. Bagian Pertama merupakan bagian pendahuluan yang memuat latar belakang serta menggambarkan tujuan, pendekatan, dan struktur penulisan. Bagian Kedua merupakan Pembahasan yang menganalisis konsep dan pengaturan Kombatan dalam Hukum Humaniter Internasional, membahas status Pasukan Kesultanan Sulu, menganalisis jenis konflik berdasarkan perspektif Hukum Humaniter Internasional, dan mengemukakan gagasan mengenai kualifikasi Grey Zone Conflict dalam sengketa antara Kesultanan Sulu-Malaysia. Terakhir, akan dikemukakan kesimpulan yang menyarikan pembahasan yang dilakukan dalam artikel ini.

\section{Pembahasan}

\subsection{Kombatan dalam Hukum Humaniter Internasional}

Istilah kombatan cukup sering digunakan secara awam untuk merujuk para pihak dalam peperangan. Dalam Hukum Humaniter Internasional, definisi kombatan dapat ditemukan di dalam Artikel 43 (2) Protokol Tambahan I 1977 yang menyatakan sebagai berikut, "Member of the armed forces of a Party to a conflict (other than medical personel and chaplains ...) are combatants, that is to say, they have the right to participate directly in hostilities." Dapat dimaknai dari ketentuan tersebut bahwa kombatan adalah anggota angkatan bersenjata dari suatu pihak yang berkonflik yang memiliki hak untuk terlibat langsung dalam suatu konflik bersenjata. Ditentukan pula bahwa anggota angkatan bersenjata sebagaimana dimaksud tidaklah meliputi personil medis dan rohaniawan militer.

Sebagai implementasi atas prinsip pembedaan, kombatan diwajibkan untuk setiap saat membedakan dirinya dengan penduduk sipil. Hal ini ditentukan oleh Artikel 44 (3) Protokol Tambahan I 1977, yang menyatakan sebagai berikut, "In order to promote the protection of the civilian population from the effects of hostilities, combatants are obliged to distinguish themselves from the civilian population when they are engaged in an attack or in military operation preparatory to an attack." Ketentuan ini dapat dimaknai sebagai upaya untuk melindungi penduduk sipil dari dampak peperangan.

Karakteristik kombatan yang agresif menyerang pihak lawan menjadikan kombatan dapat diserang setiap saat selama konflik berlangsung. Apabila mereka menyerah atau menjadi hors de combat, mereka tidak lagi dapat diserang, demikian pula halnya apabila mereka mundur dari tindakan permusuhan melalui pensiun atau purna tugas, mobilisasi atau pemindahan. ${ }^{14}$ Kombatan yang jatuh ke tangan musuh harus memperoleh haknya sebagai tawanan perang sebagaimana diatur berdasarkan Hukum Humaniter Internasional, khususnya Konvensi Jenewa III 1949.

Sejumlah entitas juga dapat dikategorikan sebagai kombatan, termasuk di antaranya regular troops, milisi dan korps sukarelawan atau mereka yang biasa disebut member of other

14 Lihat Gary D. Solis. 2010. The Law of Armed Conflict. New York: Cambridge University Press, h. 188. 
militias and member of other volunteer, adalah mereka yang tergolong sebagai partisan dan gerilyawan, yang dapat turut serta dalam tindakan permusuhan. Persyaratan terhadap kombatan dapat ditemukan di dalam Artikel 1 Annex to the Convention Regulations Respecting the Laws and Customs of War on Land (biasa disebut sebagai Hague Regulations), sebagai berikut:

"The laws, rights, and duties of war apply not only to armies, but also to militia and volunteer corps fulfilling the following conditions:

1. To be commanded by a person responsible for his subordinates;

2. To have a fixed distinctive emblem recognizable at a distance;

3. To carry arms openly; and

4. To conduct their operations in accordance with the laws and customs of war.

In countries where militia or volunteer corps constitute the army, or form part of it, they are included under the denomination "army."

Berdasarkan ketentuan tersebut, maka milisi dan korps sukarelawan ketika telah memenuhi persyaratan tersebut di atas dianggap sebagai kombatan yang resmi atau sah.

Selanjutnya, Artikel 2 Hague Regulations menyatakan sebagai berikut:

"The inhabitants of territory which has not been occupied, who on the approach of the enemy, spontaneously take arms to resist the invading troops without having had time to organize themselves in accordance with Article 1, shall be regarded as the belligerents if they carry arms openly and if they respect the laws and customs of war"

Ketentuan di atas menjelaskan mengenai siapa yang dianggap sebagai levee en masse yang bersifat temporal, artinya penduduk yang melakukan perlawanan dengan cara mengorganisir dirinya. ${ }^{15}$ Istilah dari levee en masse muncul pada tahun 1789 pada saat terjadinya Revolusi Perancis, kemudian mulai mencuat kembali di tahun 1941 dua minggu setelah peristiwa Pearl Harbour, ketika Jepang akan menguasai Pulau Wake. Saat itu lebih dari seratus orang penduduk Amerika Serikat yang bekerja sebagai pekerja bangunan di pulau tersebut tewas. Bahkan terdapat lebih dari enam puluh orang yang tewas disebabkan karena mereka melakukan perlawanan terhadap tentara Jepang, dalam rangka mempertahankan pulau tersebut. ${ }^{16}$

Dari penjelasan tersebut, menjadi jelas bahwa peserta perang atau kombatan yaitu para pihak yang secara langsung terlibat dalam permusuhan bersenjata yang terdiri dari :

1. Tentara reguler suatu pihak dalam perjanjian (Negara)

2. Milisi atau korps sukarela yang memenuhi unsur sebagaimana tercantum dalam Bab I Hague Regulations

3. Levee en masse, sebagaimana yang tercantum dalam Artikel 2 Hague Regulations

\footnotetext{
${ }^{15}$ Lihat Arlina Permatasari, dkk. 1998. Pengantar Hukum Humaniter. Jakarta: Penerbit ICRC, h. 78.

${ }^{16}$ Gary D. Solis, Op.Cit., h. 200.
} 


\subsection{Apakah Pasukan Kesultanan Sulu Merupakan Kombatan?}

Status para pihak yang terlibat dalam konflik bersenjata pada kasus ini tentu perlu untuk diperjelas. Di satu sisi, Tentara Pemerintah Malaysia merupakan angkatan bersenjata sah dari suatu negara berdaulat, sehingga statusnya sebagai kombatan amat jelas. Di sisi lain, terdapat pertanyaan berkaitan dengan status pasukan Kesultanan Sulu, apakah mereka merupakan kombatan ataukah tidak.

Uraian pada bagian 2.1 dapat digunakan untuk menganalisa status pasukan Kesultanan Sulu, sebagaimana terdeskripsikan pada tabel di bawah ini:

Tabel 1

Identifikasi status Kombatan untuk Pasukan Kesultanan Sulu

berdasarkan Hague Regulations

\begin{tabular}{|c|c|c|c|}
\hline No & Hague Regulations & $\begin{array}{l}\text { Karakteristik Pasukan } \\
\text { Kesultanan Sulu }\end{array}$ & Keterangan \\
\hline 1 & $\begin{array}{l}\text { To be commanded by a } \\
\text { person responsible for his } \\
\text { subordinates }\end{array}$ & $\begin{array}{l}\text { Pasukan Kesultanan Sulu } \\
\text { dipimpin oleh Raja Muda Ag- } \\
\text { bimuddin Kiram, adik dari } \\
\text { Sultan Sulu. }\end{array}$ & $\begin{array}{l}\text { Memenuhi unsur adanya } \\
\text { pimpinan yang bertang- } \\
\text { gung jawab. }\end{array}$ \\
\hline 2 & $\begin{array}{l}\text { To have a fixed distinctive } \\
\text { emblem recognizable at a } \\
\text { distance }\end{array}$ & $\begin{array}{l}\text { Pasukan Sulu menggunakan } \\
\text { tipe serta motif yang serupa } \\
\text { dengan seragam yang biasa } \\
\text { digunakan tentara (doreng), } \\
\text { dengan identitas bendera Mer- } \\
\text { ah di lengan sebelah kanan. }\end{array}$ & $\begin{array}{l}\text { Memenuhi unsur meng- } \\
\text { gunakan tanda-tanda } \\
\text { pembeda yang permanen, } \\
\text { dalam hal ini adalah se- } \\
\text { ragam }\end{array}$ \\
\hline 3 & To carry arms openly & $\begin{array}{l}\text { Dalam melakukan penyeran- } \\
\text { gan terhadap Sabah-Malaysia, } \\
\text { pasukan Sulu secara jelas } \\
\text { membawa dan menggunakan } \\
\text { senjata }\end{array}$ & $\begin{array}{l}\text { Memenuhi unsur memba- } \\
\text { wa senjata secara terang- } \\
\text { terangan }\end{array}$ \\
\hline 4 & $\begin{array}{l}\text { To conduct their opera- } \\
\text { tions in accordance with } \\
\text { the laws and customs of } \\
\text { war }\end{array}$ & $\begin{array}{l}\text { Common Articles } 2 \text { Konvensi } \\
\text { Jenewa } 1949 \text { menentukan } \\
\text { bahwa Perang haruslah diu- } \\
\text { mumkan. Fakta menunjukkan } \\
\text { bahwa pasukan Kesultanan } \\
\text { Sulu pada awal Februari } 2013 \\
\text { menerobos wilayah Malaysia } \\
\text { secara seketika. }\end{array}$ & $\begin{array}{l}\text { Tidak melaksanakan } \\
\text { prosedur konflik bersen- } \\
\text { jata, yaitu perang yang } \\
\text { diumumkan }\end{array}$ \\
\hline 5 & $\begin{array}{l}\text { In countries where militia } \\
\text { or volunteer corps con- } \\
\text { stitute the army, or form } \\
\text { part of it, they are included } \\
\text { under the denomination } \\
\text { "army" }\end{array}$ & $\begin{array}{l}\text { Jelas bahwa tentara Kesultan- } \\
\text { an Sulu bukan tentara Reguler } \\
\text { Filipina karena baik tempat } \\
\text { kedudukannya maupun ke- } \\
\text { beradaannya tidak diakui oleh } \\
\text { Pemerintah Filipina. }\end{array}$ & $\begin{array}{l}\text { Tidak adanya pengakuan } \\
\text { dari Negara tempat } \\
\text { kedudukan Kesultanan } \\
\text { Sulu, yaitu Filipina. }\end{array}$ \\
\hline
\end{tabular}


Ketentuan dalam Hague Regulations berlaku kumulatif. Berdasarkan uraian pada tabel di atas yang menguji dan menganalisis bahwa dua dari lima unsur tidak terpenuhi, maka dapat diambil kesimpulan bahwa pasukan Kesultanan Sulu tidak bisa dikatakan sebagai kombatan.

Pertanyaan yang kemudian muncul adalah, jika pasukan Kesultanan Sulu tidak dapat dikategorikan sebagai kombatan, maka bagaimana mereka dapat dikualifikasikan berdasarkan Hukum Humaniter Internasional? Dapat kiranya dikemukakan bahwa pasukan Kesultanan Sulu dapat disebut sebagai suatu unlawful combatant. International Committee of the Red Cross (ICRC) Legal Advisory mendeskripsikan apa yang disebut sebagai unlawful combatant sebagai, berikut "All persons taking a direct part in hostilities without being entitled to do so and who thereof cannot be classified as prisoners of war on falling into the power of the enemy (one might add to that definition that the persons taking a direct part must be civilians)." 17 Menurut deskripsi tersebut, mereka yang disebut sebagai "unlawful combatant" adalah orangorang yang terlibat dalam tindakan permusuhan akan tetapi tidak dapat memperoleh haknya sebagai tawanan perang.

Istilah unlawful combatant pertama kali muncul pada tahun 1951 dalam artikel yang ditulis oleh Richard Baxter yang menyebut unlawful combatant sebagai unprevileged belligerents. ${ }^{18}$ Unlawful combatant secara konseptual dapat terdiri dari sebuah grup yang terorganisir. Walaupun tidak mendapat status sebagai tawanan perang, apabila unlawful combatant tertangkap, mereka harus diperlakukan secara manusiawi dan mendapatkan perlakuan minimum tanpa diskriminasi. ${ }^{19}$ Dengan demikian, status pasukan Kesultanan Sulu sebagai unlawful combatant mengandung konsekuensi bahwa dalam hal mereka tertangkap oleh pihak berwenang Malaysia, kendatipun mereka tidak berstatus sebagai tawanan perang, maka mereka tetap harus diperlakukan secara manusiawi.

\subsection{Jenis-Jenis Konflik Bersenjata Berdasarkan Hukum Humaniter Internasional}

"Sengketa bersenjata" atau "konflik bersenjata" (armed conflict) merupakan perisitilahan yang digunakan untuk menggantikan istilah perang "war". Dalam dunia modern, perang atau konflik bersenjata diartikan sebagai suatu bentuk perjuangan antara dua Negara/bangsa atau lebih yang bertujuan untuk mewujudkan kepentingan politik nasionalnya yang berbeda secara mendasar dan berakibat tidak dapat dipertemukannya ideologi antara kedua belah pihak, dengan segala alat-alat dan cara-cara yang terdapat di Negara-negara tersebut. ${ }^{20}$

\footnotetext{
${ }^{17}$ Ibid, h. 207.

18 Ibid, h. 208.

${ }^{19}$ Lihat Artikel 75 Protokol Tambahan I 1977.

${ }^{20}$ F. Sugeng Istanto. 1998. Hukum Internasional. Yogyakarta: Penerbit Universitas Atma Jaya, h.104. Lihat pula Mahfud. Langkah Pencegahan Konflik Bersenjata (The Preventing Measures of Armed Conflict), Ubelaj, Volume 1 Issue 1, October 2016, h. 84-85, https://ejournal.unib.ac.id/index.php/ubelaj/article/download/1328/1120
} 
Haryomataram membagi konflik bersenjata sebagai berikut: ${ }^{21}$

1) Konflik bersenjata internasional, yang dapat dibedakan menjadi 2 macam, yaitu:

(a) Konflik bersenjata internasional murni

(b) Konflik bersenjata internasional semu, yang dapat dibedakan menjadi 2 jenis, yaitu:

(1) Perang pembebasan nasional (war of national liberation).

(2) Konflik bersenjata internal yang diinternasionalisir (internationalized internal armed conflict).

2) Konflik Bersenjata Non-Internasional

(a) Konflik Bersenjata yang tunduk pada Artikel 3 Konvensi Jenewa 1949.

(b) Konflik Bersenjata yang tunduk pada Protokol Tambahan II 1977.

a) Berdasarkan sistematika pengertian yang diberikan oleh Haryomataram dan sesuai dengan Konvensi Jenewa 1949 dan Protokol Tambahan 1977, akan diuraikan lebih lanjut mengenai perbedaan antara Konflik Bersenjata Internasional dan Konflik Bersenjata Non-Internasional

b) Konflik Bersenjata Internasional

Konvensi-Konvensi Jenewa 1949 secara umum mengatur mengenai konflik bersenjata yang bersifat internasional (international armed conflict), yaitu perang yang terjadi antar Negara. ${ }^{22}$ ICRC memberikan pengertian konflik bersenjata internasional yang didasarkan pada Protokol Tambahan I 1977, yaitu: "Fighting between the armed force of at least two states it should be noted that wars of national liberation have been classified as international armed conflict". ${ }^{23}$ Konflik bersenjata yang bersifat internasional merupakan perang atau konflik bersenjata yang terjadi antar negara (inter-state war), di mana yang menjadi subyeknya adalah negara-negara, serta mencakup pula perang pembebasan nasional. Pengaturan konflik bersenjata jenis ini dapat dilihat dari Common Articles 2 Konvensi Jenewa 1949 dan Artikel 1 (3) Protokol Tambahan I 1977.

Konvensi-Konvensi Den Haag 1907, Konvensi-Konvensi Jenewa 1949 dan Protokol Tambahan I 1977 berlaku dalam konflik bersenjata internasional, sepanjang pihak yang bertikai telah meratifikasinya. Dengan melihat kepada Artikel 1 (3) dan Artikel 1 (4) Protokol

\footnotetext{
${ }^{21}$ Haryomataram. 2002. Konflik Bersenjata dan Hukumnya. Jakarta: Penerbit Universitas Trisakti, h. 7.

22 Bathlimus. 2002. Perlindungan Hukum bagi Anak yang Terlibat atau Terkena Dampak dari Situasi Konflik di Indonesia. Jakarta: Penerbit ICRC, h. 41.

${ }^{23}$ International Committee of the Red Cross, 2002, International Humanitarian Law: Answers to your Questions, Geneva: International Committee of the Red Cross, h.4. https://www.icrc.org/eng/assets/files/other/icrc_002_0703.pdf
} 
Tambahan I 1977 maka dapat disimpulkan bahwa yang dimaksud konflik bersenjata yang bersifat internasional dapat dikelompokkan ke dalam 2 (dua) hal, yaitu:

1) Konflik Bersenjata Antar Negara

2) Konflik Bersenjata Antara penduduk melawan kolonialisme, berupa okupasi dari pihak asing dan rezim rasisme (CAR conflicts) yang sering disebut war of national liberation.

b) Konflik Bersenjata Non-Internasional

Common Articles 3 Konvensi Jenewa 1949 menggunakan istilah konflik bersenjata yang tidak bersifat internasional (armed conflict not of an international character) untuk jenis konflik bersenjata non-internasional. Penafsiran ketentuan ini sangat luas karena konflik bersenjata non-internasional dilihat dari status hukum para pihak yang bersengketa tidak sama antara pihak yang satu dan pihak yang lain dalam satu Negara. Di samping itu, konflik bersenjata non-internasional dapat pula terjadi pada situasi di mana faksi-faksi yang bersenjata (armed factions) saling bermusuhan satu sama lain tanpa terjadinya intervensi dari angkatan bersenjata yang sah. ${ }^{24}$

Konflik bersenjata yang terjadi di dalam suatu wilayah Negara kadang-kadang dapat berlangsung dalam jangka waktu yang relatif lama. Bahkan dalam sejumlah kasus, kapasitas militer kaum pemberontak juga cukup mampu mengimbangi kekuatan pasukan pemerintah yang sah. Kemudian para ahli hukum internasional membagi golongan pemberontak menjadi dua golongan, yaitu kaum insurgent dan kaum belligerent.

Kaum insurgent masih berada pada tingkat yang belum besar cakupannya dan cenderung belum memiliki susunan yang teratur. Biasanya peristiwa pemberontakan itu hanya menjadi masalah dalam negeri dari negara yang bersangkutan saja. Adapun kaum belligerent adalah golongan kaum pemberontak yang lebih kuat, memiliki susunan organisasi yang tetap, dan mapan dari segi politik. ${ }^{25}$ Dalam konflik ini, entitas dari loyalis Kesultanan Sulu tidak bisa dikategorikan baik sebagai insurgent maupun belligerent.

Klaim status pemberontah tidak secara otomatis menjadikan suatu situasi dapat dikategorikan sebagai Konflik Bersenjata Non Internasional. Berikut merupakan syarat-syarat terjadinya konflik bersenjata non-internasional di suatu wilayah negara:

1) Bahwa pihak yang memberontak terhadap pemerintah de jure memiliki kekuatan militer yang terorganisir, dipimpin oleh seorang komandan yang bertanggung jawab terhadap anak buahnya, melakukan aksi dalam wilayah tertentu dan memiliki sarana untuk menghormati dan menjamin penghormatan terhadap Konvensi Jenewa;

24 Arlina Permatasari dkk. Op.Cit., h. 143.

25 Berkaitan dengan penjelasan ini, lihat Artikel Pengaturan Hukum Internasional Mengenai Pemberontak Sebagai Salah Satu Subjek Hukum Internasional, http://www.landasanteori.com/2015/09/pengaturan-hukum-internasional-mengenai.html 
2) Bahwa pemerintah yang sah dipaksa untuk menggerakkan kekuatan militer reguler untuk menghadapi pemberontak yang terorganisir secara militer dan menguasai sebagian wilayah nasional.

Tabel 2

Analisa konflik bersenjata Sulu-Malaysia

berdasarkan Perspektif Hukum Humaniter Internasional

\begin{tabular}{|c|c|c|c|c|}
\hline No & Uraian & $\begin{array}{l}\text { Konflik Bersenjata } \\
\text { Internasional }\end{array}$ & $\begin{array}{c}\text { Konflik Bersenjata non } \\
\text { Internasional }\end{array}$ & $\begin{array}{l}\text { Konflik Bersenjata Ke- } \\
\text { sultanan Sulu-Malaysia }\end{array}$ \\
\hline 1 & Para Pihak & $\begin{array}{l}\text { 1. Konflik bersenjata } \\
\text { yang terjadi antar } \\
\text { negara (inter-state } \\
\text { war), di mana } \\
\text { yang menjadi } \\
\text { subyeknya adalah } \\
\text { negara-negara. } \\
\text { 2. Konflik Bersen- } \\
\text { jata antara pen- } \\
\text { duduk melawan } \\
\text { kolo n i ali s me, } \\
\text { berupa okupasi } \\
\text { dari pihak asing } \\
\text { dan rezim rasisme } \\
\text { (CAR conflicts) } \\
\text { yang sering dis- } \\
\text { ebut War of Na- } \\
\text { tional Liberation } \\
\text { (Artikel } 1 \text { (3) dan (4) } \\
\text { Protokol Tambahan } 1 \\
\text { 1977) }\end{array}$ & $\begin{array}{l}\text { 1. Konflik bersenjata } \\
\text { yang terjadi antara } \\
\text { pemerintah yang } \\
\text { sah dengan kelom- } \\
\text { pok-kelompok ber- } \\
\text { senjata yang teror- } \\
\text { ganisir (organized } \\
\text { armed groups) } \\
\text { 2. konflik bersenjata } \\
\text { non-internasional } \\
\text { dapat pula terjadi } \\
\text { pada situasi di } \\
\text { mana faksi-faksi } \\
\text { yang bersenjata } \\
\text { (armed factions) } \\
\text { saling bermusuhan } \\
\text { satu sama lain tan- } \\
\text { pa terjadinya inter- } \\
\text { vensi dari angkatan } \\
\text { bersenjata yang sah } \\
\text { (Common Articles } \\
\text { Konvensi Jenewa } \\
\text { 1949) }\end{array}$ & $\begin{array}{l}\text { Karakteristik sengketa } \\
\text { bersenjata interna- } \\
\text { sional tidak terpenuhi } \\
\text { karena konflik bukan } \\
\text { antar Negara, ataupun } \\
\text { bukan perang melawan } \\
\text { penjajahan. Sengketa } \\
\text { ini juga tidak termasuk } \\
\text { dalam kategori konflik } \\
\text { bersenjata non interna- } \\
\text { sional sebagaimana ter- } \\
\text { maktub dalam Common } \\
\text { Articles } 3 \text { Konvensi Je- } \\
\text { newa 1949. Faktanya, } \\
\text { pasukan Kesultanan } \\
\text { Sulu yang berkedudu- } \\
\text { kan di Filipina tidaklah } \\
\text { melawan pemerintah } \\
\text { Filipina, melainkan } \\
\text { melawan pemerintah } \\
\text { Negara lainnya yaitu } \\
\text { Malaysia }\end{array}$ \\
\hline 2 & $\begin{array}{l}\text { Karakteristik para } \\
\text { pihak }\end{array}$ & $\begin{array}{l}\text { Komentar dari Pro- } \\
\text { tokol Tambahan I 1977 } \\
\text { menyebutkan bahwa } \\
\text { konflik bersenjata } \\
\text { yang dimaksud ada- } \\
\text { lah konflik bersenjata } \\
\text { yang terjadi antara } \\
\text { dua atau lebih Pihak } \\
\text { Agung dengan yang } \\
\text { bukan Pihak Peserta }\end{array}$ & $\begin{array}{l}\text { 1. Bahwa pihak yang } \\
\text { memberontak ter- } \\
\text { hadap pemerintah } \\
\text { de jure memiliki } \\
\text { kekuatan militer } \\
\text { yang terorganisir, } \\
\text { dipimpin oleh se- } \\
\text { orang komandan } \\
\text { yang bertanggung } \\
\text { jawab terhadap } \\
\text { anak buahnya, }\end{array}$ & $\begin{array}{l}\text { Uraian } 2.2 \text { secara jelas } \\
\text { menganalisis bahwa } \\
\text { hanya satu pihak yang } \\
\text { dapat dikualifikasikan } \\
\text { sebagai kombatan, yak- } \\
\text { ni pasukan Malaysia } \\
\text { yang merupakan ten- } \\
\text { tara sah dari suatu neg- } \\
\text { ara berdaulat. Adapun } \\
\text { pasukan Kesultanan }\end{array}$ \\
\hline
\end{tabular}




\begin{tabular}{|c|c|c|c|c|c|}
\hline & & $\begin{array}{l}\text { Agung asalkan yang } \\
\text { terakhir juga berben- } \\
\text { tuk Negara }\end{array}$ & & $\begin{array}{l}\text { melakukan aksi } \\
\text { dalam wilayah ter- } \\
\text { tentu dan memiliki } \\
\text { sarana untuk meng- } \\
\text { hormati dan menja- } \\
\text { min penghormatan } \\
\text { terhadap Konvensi } \\
\text { Jenewa } 1949 \\
\text { Bahwa pemerintah } \\
\text { yang sah dipaksa } \\
\text { untuk menggerak- } \\
\text { kan kekuatan mi- } \\
\text { liter reguler untuk } \\
\text { menghadapi pem- } \\
\text { berontak yang ter- } \\
\text { organisir secara mi- } \\
\text { liter dan menguasai } \\
\text { sebagian wilayah } \\
\text { nasional }\end{array}$ & $\begin{array}{ll}\text { Sulu justru merupakan } \\
\text { unlawful } & \text { combatant. }\end{array}$ \\
\hline
\end{tabular}

Berdasarkan tabel di atas menjadi jelas bahwa karakteristik konflik bersenjata yang terjadi di wilayah Sabah-Malaysia antara Kesultanan Sulu (yang berkedudukan di wilayah kedaulatan Filipina) dengan Malaysia berbeda dari penjabaran Konvensi Jenewa 1949 dan Protokol Tambahan I dan II 1977. Sengketa ini tidak dapat dikategorikan baik sebagai konflik bersenjata internasional maupun konflik bersenjata non-Internasional. Secara faktual, konflik bersenjata ini terjadi antara pasukan terorganisir Kesultanan Sulu melawan pemerintahan Negara lainnya, yakni Filipina.

\subsection{Konflik antara Kesultanan Sulu-Malaysia: A Grey Zone Conflict?}

Dalam perkembangannya, selain konflik bersenjata internasional dan konflik bersenjata non internasional terdapat pula konsep yang disebut sebagai grey zone conflict. ${ }^{26}$ Istilah ini mungkin relatif baru, namun fenomena yang terjadi sesungguhnya sudah berlangsung lama. ${ }^{27}$ Grey zone conflict ini merupakan situasi konflik yang terjadi karena adanya gangguan internal dan kerusuhan, seperti kerusuhan, terisolasi dan tindakan kekerasan sporadis yang biasanya disebabkan oleh masalah tentang agama, suku, politik, sosial maupun ekonomi. Grey zone conflict tidak termasuk kategori dalam konflik bersenjata internasional karena terjadi dalam wilayah suatu negara antara angkatan perang negara tersebut dengan gerombolan bersenjata dan juga tidak termasuk konflik bersenjata non internasional.

26 Haryomataram. Op.Cit., h. 39.

27 United States Department of State, Report on Gray Zone Conflict, International Security Advisory Board, January 3, 2017, h.1, https://www.state.gov/documents/organization/266849.pdf 
Michael J. Mazarr menggambarkan konflik jenis ini sebagai berikut, "Gray zone conflict involves the holistic application of a mosaic of civilian and military tools, short of combat operations, to achieve gradual progress toward political objectives.... It creates a blended version of conflict by blurring the boundary between peace and war, and civilian and military tools and categories "28 Dari deskripsi tersebut, dapat dimaknai bahwa konflik jenis ini melibatkan penerapan holistik dari suatu mosaik alat sipil dan militer, operasi tempur yang singkat, untuk mencapai kemajuan bertahap menuju tujuan politik yang hendak dicapai. Grey zone conflict juga menciptakan versi perpaduan konflik dengan mengaburkan batas antara perdamaian dan perang, serta sarana dan kategori penduduk sipil dan militer.

Apabila ditinjau dari latar belakang serangan pasukan Sulu ke Sabah, yaitu sejarah politik di masa lampau sebagaimana diuraikan pada bagian 1.1, maka sengketa bersenjata ini dapat dikategorikan sebagai suatu grey zone conflict. Demikian pula halnya dengan analisis pada bagian 2.2 dan 2.3 dari tulisan ini yang melakukan eksaminasi konsep dan aturan yang berkaitan dengan status pasukan Kesultanan Sulu dan jenis konflik bersenjata berdasarkan Hukum Humaniter Internasional, maka kualifikasi grey zone conflict dalam konflik tersebut semakin dapat dikemukakan.

\section{PENUTUP}

Dalam konflik bersenjata antara Kesultanan Sulu dan Malaysia, status pasukan Kesultanan Sulu tidak memenuhi seluruh unsur kombatan sebagaimana disyaratkan dalam Hukum Humaniter Internasional. Secara konseptual, pasukan ini lebih tepat dikualifikasikan sebagai unlawful combatant. Dalam klasifikasi ini, status pasukan Kesultanan Sulu unlawful combatant mengandung konsekuensi bahwa dalam hal mereka tertangkap oleh pihak berwenang Malaysia, kendatipun mereka tidak berstatus sebagai tawanan perang, maka mereka tetap harus diperlakukan secara manusiawi. Dari segi jenisnya, sengketa bersenjata antara Kesultanan Sulu dan Malaysia tidak dapat dikategorikan baik sebagai konflik bersenjata internasional maupun konflik bersenjata non internasional. Konflik ini tidak termasuk ke dalam konflik bersenjata internasional karena terjadi dalam wilayah suatu negara, antara angkatan perang negara tersebut dengan gerombolan bersenjata. Konflik ini juga tidak tergolong konflik bersenjata non internasional karena tidak atau belum melampaui "ambang" (threshold) yang ditentukan. Pada dasarnya, sengketa ini memiliki karakteristik pihak yang berbeda yaitu di satu sisi Pemerintahan suatu Negara yang sah, yakni Malaysia, dan di sisi yang berlawanan gerakan terorganisir yang berkedudukan di Negara lainnya, yakni pasukan Kesultanan Sulu yang berkedudukan di Filipina. Mencermati latar belakang serangan suku Sulu ke Sabah-Malaysia serta eksaminasi konsep dan aturan yang berkaitan dengan status pasukan Kesultanan Sulu dan jenis konflik bersenjata berdasarkan Hukum Humaniter Internasional, maka sengketa bersenjata antara Kesultanan Sulu dan Malaysia dapat dikategorikan sebagai suatu grey zone conflict.

28 Michael J. Mazarr. Mastering The Gray Zone: Understanding a Changing Era of Conflict, Strategic Studies Institute and U.S. Army War College Press, December 2015, h. 63, https://ssi.armywarcollege.edu/pdffiles/PUB1303.pdf 


\section{DAFTAR PUSTAKA}

\section{A. Buku}

Bathlimus. 2002. Perlindungan Hukum bagi Anak yang Terlibat atau Terkena Dampak dari Situasi Konflik di Indonesia. Jakarta: Penerbit ICRC.

Haryomataram. 2002. Konflik Bersenjata dan Hukumnya. Jakarta: Penerbit Universitas Trisakti.

International Committee of the Red Cross, 2002, International Humanitarian Law: Answers to your Questions, Geneva: International Committee of the Red Cross

Istanto, F. Sugeng. 1998. Hukum Internasional. Yogyakarta: Penerbit Universitas Atma Jaya.

Permatasari, Arlina, dkk. 1998. Pengantar Hukum Humaniter. Jakarta: Penerbit ICRC.

Solis, Gary D. 2010. The Law of Armed Conflict. New York: Cambridge University Press.

\section{B. Jurnal dan Paper}

Ilyasa, Reza, Herman Suryokumoro, Ikaningtyas. Serangan Bersenjata Kesultanan Sulu Terhadap Wilayah Sabah Malaysia Berdasarkan Perspektif Hukum Humaniter Internasional, https://media.neliti.com/media/publications/35369-ID-serangan-bersenjata-kesultanan-sulu-terhadapwilayah-sabah-malaysia-berdasarkan.pdf

Mahfud. Langkah Pencegahan Konflik Bersenjata (The Preventing Measures of Armed Conflict), Ubelaj, Volume 1 Issue 1, October 2016, h. 84-85, https://ejournal.unib.ac.id/index.php/ubelaj/article/download/1328/1120

Mazarr, Michael J. Mastering The Gray Zone: Understanding a Changing Era of Conflict, Strategic Studies Institute and U.S. Army War College Press, December 2015, h. 63, https://ssi.armywarcollege.edu/pdffiles/PUB1303.pdf

Roza, Rizki. Konflik Sulu-Malaysia: Ancaman Terhadap Keamanan Kawasan?, Info Singkat, Hubungan Internasional, Pusat Pengkajian, Pengolahan Data dan Informasi (P3DI) Sekretariat Jenderal DPR RI, Vol. V, No. 05/I/P3DI/Maret/2013, http://berkas.dpr.go.id/puslit/files/info_ singkat/Info\%20Singkat-V-5-I-P3DI-Maret-2013-75.pdf

Siburian, Adrianus dan Faisyal Rani. Diplomasi Malaysia Terhadap Kesultanan Sulu (Filipina) Dalam Perebutan Wilayah Sabah, 2013, http://repository.unri.ac.id/xmlui/bitstream/ handle/123456789/6121/Jurnal\%20DIPLOMASI\%20MALAYSIA\%20TERHADAP\%20KESULTANAN\%20SULU\%201.pdf? sequence $=1$ 
KERTHA PATRIKA

Volume 39, Nomor 1, April 2017

\section{Internet}

Allison, Ewen., Goldman, K. Robert., Grey Areas In International Humanitarian Law (online), http:// www.crimesofwar.org/a-z-guide/gray-areas-in-international-humanitarian-law

Arfi Bambani Amri, Akar Perang Sulu-Malaysia:Warisan konflik kolonial: Antara Bayar Sewa dan Penyerahan, Viva.co.id, 8 Maret 2013, http://sorot.news.viva.co.id/news/read/396304-akar-perang-sulumalaysia

Egidius Patnistik (ed), Liku-liku Sejarah Klaim Sabah, Kompas.com, 6 Maret 2013, https://app.kompas. com/amp/internasional/read/2013/03/06/08064895/Likuliku.Sejarah.Klaim.Sabah

Artikel, Perjalanan Pulang' Keluarga Sultan Sulu ke Sabah, Tempo.Co, 5 Maret 2013,HTTPS:/M.TEMPO. CO/READ/NEWS/2013/03/05/115465135/PERJALANAN-PULANG-KELUARGA-SULTANSULU-KE-SABAH

Artikel, Sabah oh sabah: Masa Lalu yang Belum Tuntas di Sabah, Warta Riau, 5 Maret 2013, http://www. wartariau.com/read-714-2013-03-05--masa-lalu-yang-belum-tuntas-di-sabah-.html

Artikel, Masa Lalu yang Belum Tuntas di Sabah, Kompas.com, 5 Maret 2013, http://bola.kompas.com/ $\mathrm{read} / 2013 / 03 / 05 / 08185514 /$ Masa.Lalu.yang.Belum.Tuntas.di.Sabah

\section{Instrumen Internasional}

Annex to the Convention Regulations Respecting the Laws and Customs of War on Land (Hague Regulations) 1907

Geneva Conventions of 1949 (Konvensi-Konvensi Jenewa 1949)

Protocol Additional to the Geneva Conventions of 12 August 1949, and Relating to the Protection of Victims of International Armed Conflicts (Protocol I), of 8 June 1977 (Protokol Tambahan I 1977)

Protocol Additional to the Geneva Conventions of 12 August 1949, and Relating to the Protection of Victims of Non-International Armed Conflicts (Protocol II), of 8 June 1977 (Protokol Tambahan II 1977)

United States Department of State, Report on Gray Zone Conflict, International Security Advisory Board January 3, 2017, https://www.state.gov/documents/organization/266849.pdf 